\title{
Enhancement of fructosyltransferase and fructooligosaccharides production by A. oryzae DIA-MF in Solid-State Fermentation using aguamiel as culture medium
}

\author{
Diana B. Muñiz-Márquez a , Juan C. Contreras a ${ }^{a}$, Raúl Rodríguez ${ }^{a}$, Solange I. Mussatto ${ }^{\text {b }}$, José A. Teixeira ${ }^{\text {, }}$, \\ Cristóbal N. Aguilar ${ }^{\mathrm{a}, *}$
}

${ }^{a}$ Group of Bioprocesses, Food Research Department, School of Chemistry, University Autonomous of Coahuila, 25280 Saltillo, Coahuila, Mexico

${ }^{\mathrm{b}}$ Department of Biotechnology, Delft University of Technology, Julianalaan 67, 2628 BC Delft, Netherlands

${ }^{\mathrm{c}}$ IBB - Institute for Biotechnology and Bioengineering, Centre of Biological Engineering, University of Minho, Campus Gualtar, $4710-057$ Braga, Portugal

\section{H I G H L I G H T S}

- Aguamiel is a potential source for production of fructosyltransferases enzymes.

- FOS production in aguamiel as substrate is a viable alternative.

- Fructosyltransferase and FOS production by Solid State Fermentation is a viable and economic alternative.

\section{A R T I C L E I N F O}

\section{Article history:}

Received 31 December 2015

Received in revised form 1 March 2016

Accepted 2 March 2016

Available online 19 March 2016

\section{Keywords:}

Fructosyltransferase

Fructooligosaccharides

Aguamiel

Solid State Fermentation

\begin{abstract}
A B S T R A C T
The aim of this work was to improve the production of fructosyltransferase (FTase) by Solid-State Fermentation (SSF) using aguamiel (agave sap) as culture medium and Aspergillus oryzae DIA-MF as producer strain. SSF was carried out evaluating the following parameters: inoculum rate, incubation temperature, initial $\mathrm{pH}$ and packing density to determine the most significant factors through Box-Hunter and Hunter design. The significant factors were then further optimized using a Box-Behnken design and response surface methodology. The maximum FTase activity $(1347 \mathrm{U} / \mathrm{L})$ was obtained at $32{ }^{\circ} \mathrm{C}$, using packing density of $0.7 \mathrm{~g} / \mathrm{cm}^{3}$. Inoculum rate and initial $\mathrm{pH}$ had no significant influence on the response. FOS synthesis applying the enzyme produced by A. oryzae DIA-MF was also studied using aguamiel as substrate.
\end{abstract}

(c) 2016 Elsevier Ltd. All rights reserved.

\section{Introduction}

Fructooligosaccharides (FOS) are bioactive compounds with important beneficial effects, which promote a good absorption of mineral in the body, regulate blood glucose and cholesterol levels and the most important activity is the induction of the growth of probiotic microorganisms in the intestinal tract contributing to the prevention of colonic cancer (Lim et al., 2005; Rodrigues et al., 2011; Lateef and Gueguimkana, 2012; Ganaie et al., 2013; Dominguez et al., 2014). FOS are composed by one sucrose molecule linked to 1-3 units of fructose through links $\beta-2-1$ between molecules (Ganaie et al., 2014) and are commonly called 1kestose, 1-nistose and 1- $\beta$-fructofuranosylnistose (Monsan and

\footnotetext{
* Corresponding author.

E-mail address: cristobal.aguilar@uadec.edu.mx (C.N. Aguilar).
}

Ouarné, 2009; Yildiz, 2011; Barthi et al., 2013; Chen et al., 2014; Panesar et al., 2014).

Nowadays, FOS are produced commercially through microbial enzymes called $\beta$-fructofuranosidases (FFases, EC.3.2.1.26) and fructosyltransferases (FTases EC.2.4.1.9) (Hidaka et al., 1988; Pons et al., 2000; Mussatto and Teixeira, 2010; Batista et al., 2013) that have been found in fungi such as Penicillum, Aerobasidium, Fusarium and principally Aspergillus species (Antošová and Polakovič, 2001; Hernalsteens and Maugeri, 2008; Maiorano et al., 2008; Driouch et al., 2010). FFases enzymes catalyze hydrolytic and transfructosylating reactions, but their ability for transfer is only with higher sucrose amounts. On the other hand, FTases possess only transfructosylating activity, acting on the $\beta-1-2$ link of sucrose and transfer a fructose molecule to an acceptor such as other sucrose molecule leading to generation of FOS and release glucose in the reaction (Antošová and Polakovič, 2001; Ganaie et al., 2013; Šedová et al., 2014). Recent studies have been focused 
on the use of natural materials or by-products that representing an economic alternative for the FOS production, due to the increased demand by the consumption of these bioactive ingredients in the food and pharmaceutical products.

Studies on the influence of various parameters on FTase have been evaluated by different authors (Yun, 1996). However, until today, few studies are focused on Solid-State Fermentation (SSF) for the production of FTase enzyme and FOS (Mussatto et al., 2013; Sangeetha et al., 2004).

Previous studies have demonstrated that SSF is an excellent alternative to improve FOS and FTase production; however, is necessary to establish the optimal conditions to maximize the FOS and FTase production. On the other hand, the use of aguamiel as culture medium allows reducing the production costs compared with a culture medium enriched with commercial sucrose (Muñiz et al., 2015).

The aim of this experimental section was to determine the best conditions of FTase production by SSF and to improve the FOS production by the FTase produced using aguamiel (a by-product obtained the maguey and is used in Mexico for the pulque production) as substrate.

\section{Materials and methods}

\subsection{Reagents and standards}

FOS standards 1-kestose $\left(\mathrm{GF}_{2}\right)$, 1-nystose $\left(\mathrm{GF}_{3}\right)$ and $1^{\mathrm{F}}$ fructofuranosylnystose $\left(\mathrm{GF}_{4}\right)$ were purchased in Wako Pure Chemical Industries, Ltd. (Japan Company). Sugars fructose (F), glucose $(\mathrm{G})$ and sucrose $(\mathrm{S})$ were obtained from Sigma Aldrich (St. Louis, MO, USA).

\subsection{Microorganism and culture medium}

Aspergillus oryzae DIA-MF was selected in the previous step and was obtained from culture collection of molds of Food Research Department of University Autonomous of Coahuila (Mexico). Firstly, the strain was activated on potato dextrose agar (PDA) at $30 \pm 1{ }^{\circ} \mathrm{C}$ for 5 days. For the production of spores, the fungus was cultivated in flasks containing PDA medium at $28 \pm 1{ }^{\circ} \mathrm{C}$ for 5 days. A sterilized solution of $0.01 \%(\mathrm{w} / \mathrm{v})$ Tween 80 was used for harvesting the spores. The amount spores in the suspension was determined by employing a Neubauer chamber. The volume needed to give a number of spores of $2 \times 10^{7}$ spores/g support was calculated and the suspension was prepared under sterile conditions.

\subsection{Aguamiel characterization}

Aguamiel is a fluid rich in sugars obtained from maguey. In this study, the aguamiel obtaining from Agave salmiana (green maguey) was collected in February 2013 in the Mangas locality, which is close to Saltillo Coahuila, Mexico. Aguamiel was first collected and filtered with strainer, then was stored in cold temperature and transported. Afterwards it was filtered through filter paper fine pore and stored at $-18^{\circ} \mathrm{C}$. Before the physicochemical characterization, the stored aguamiel was sterilized at $15 \mathrm{lb} / 121^{\circ} \mathrm{C}$ during $15 \mathrm{~min}$. Thermal treatment was employed as method of preservation due to that aguamiel was used as culture medium (Muñiz et al., 2015).

\subsubsection{Physicochemical analysis}

Analysis of aguamiel consisted in the determination of total sugars (TS) by method Anthrone (Dreywood, 1946; Pearson et al., 1984 and Campana et al., 2006), reducing sugars (RS) by the method previously reported by Miller (1959) using 3-amino-5- dinitrosalicylic acid reagent with some modifications (Gonçalves et al., 2010), protein by Bradford's method (Bradford, 1976), lipids, ashes (i.e. mineral content), total solids, moisture and $\mathrm{pH}$ using the AOAC methods (AOAC, 1990) and degrees brix and density with a densitometer (Anton Paar, DMA 35N, Austria). All analysis were carried out in triplicate.

\subsubsection{Determination of sugars by HPLC analysis}

High performance liquid chromatography (HPLC) analysis of aguamiel consisted in identification and quantification of fructose, glucose, sucrose using a Perkin Elmer Series 200 HPLC according with the methodology described by Mussatto et al., 2009.

\subsection{Fermentation conditions}

Firstly a study of fermentation was performed in order to determine the maximum fructosyltransferase and hydrolase activities. For the assays, aguamiel of maguey (A. salmiana) previously sterilized was used as culture medium in the fermentation (Muñiz et al., 2015). Fermentation was performed in column reactors and polyurethane foam was used as inert support. Aguamiel (initial $\mathrm{pH}$ 4.5) was inoculated with $2 \times 10^{7}$ spores/g of support. The inoculated reactors were incubated at $30{ }^{\circ} \mathrm{C}$ with $70 \%$ initial moisture. Fermentation process was carried out for $48 \mathrm{~h}$ and samples were withdrawn at regular time intervals $(0,18,24,30,42$ and $48 \mathrm{~h}$ of fermentation). At the end of fermentation, crude enzymatic extract was obtained by mechanical compression of the fermented material. All experiments were carried out in duplicate. Crude extracts were filtered and analyzed by HPLC as well as for the enzymatic activities determination.

\subsection{Fructosyltransferase and hydrolase activities}

For the fructosyltransferase and hydrolase activities determination, $100 \mu \mathrm{L}$ of crude extract were mixed with $900 \mu \mathrm{L}$ of sucrose solution ( $4 \%$ in acetate buffer, $\mathrm{pH} 5.0,50 \mathrm{mM}$ ). The reaction mixture was incubated at $30^{\circ} \mathrm{C}$ for $20 \mathrm{~min}$. The reaction mixture was stopped in boiling for $3 \mathrm{~min}$. Control was prepared with sucrose and buffer without enzyme. One enzymatic unit of fructosyltransferase $(U)$ was defined as the amount of the enzyme necessary to form $1 \mu \mathrm{mol}$ of kestose per min under certain conditions. On the other hand, one enzymatic unit of hydrolase (U) was defined as the amount of the enzyme necessary to liberate $1 \mu \mathrm{mol}$ of glucose per min under certain conditions.

\subsection{FOS and sugars determination}

Crude extracts were filtered through a $0.45 \mu \mathrm{m}$ nylon membrane (Millipore) and were used for determination of FOS (1kestose, 1-nystose and $1^{\mathrm{F}}$-fructofuranosylnystose) and residual sugars (fructose, glucose and sucrose). Samples were analyzed by high performance liquid chromatography (HPLC, Perkin Elmer Series 200) using a Prevail Carbohydrate ES Column $(5 \mu \mathrm{m}$, $250 \times 4.6 \mathrm{~mm}$, Grace) at $30^{\circ} \mathrm{C}$. A mixture of acetonitrile/water $70: 30(\mathrm{v} / \mathrm{v})$ was used as mobile phase at a flow rate of $1 \mathrm{~mL} / \mathrm{min}$ with a pressure of 1700 psi. A refractive index detector (RID) was operated at $35{ }^{\circ} \mathrm{C}$. The response of the RID was recorded and integrated using the TOTALCHROM WS V6.3 software. The quantification of sugars and FOS in samples was determined by using standards curves made with known concentrations of each compound (Mussatto et al., 2009).

\subsection{Studies on the influence of various parameters}

The influence of 4 variables (inoculum, temperature, initial $\mathrm{pH}$ and packing density) affecting the fructosyltransferase production 
was evaluated using a Box-Hunter and Hunter experimental design. Then, the variables that had a significant effect on the enzymatic activity (FTase) were evaluated in a Box-Behnken design. The high and low values of the variables in the two experiments are shown in Table 1.

The Box-Behnken design was used to evaluate the significant factors on the response (FTase production). The variables studied included the inoculum $\left(2 \times 10^{7}, 3 \times 10^{7}\right.$ and $4 \times 10^{7}$ spores/g support), temperature $\left(28,30\right.$ and $\left.32{ }^{\circ} \mathrm{C}\right)$ and packing density $(0.3,0.5$ and $0.7 \mathrm{~g} / \mathrm{cm}^{3}$ ). Table 2 shows the levels used to each factor (coded values). The highest level (+1) and lowest level $(-1)$ besides a central level (0) was used in this design.

\subsection{Statistical analysis}

Statistica 7.0 software was used to identify the variables with statistically significant effect on the response. The regression coefficients for linear, quadratic and interactions for each variable were determined and adjusted to a polynomial second order equation (Eq. (1))

$Y=\beta_{0}+\beta_{1} X_{1}+\beta_{2} X_{2}+\beta_{1} X_{1}^{2}+\beta_{2} X_{2}^{2}+\beta_{1} X_{1} X_{2}+\beta_{2} X_{1} X_{2}$

where $Y=$ fructosyltransferase activity (FTase in $\mathrm{U} / \mathrm{L}$ of crude extract), $X_{1}$ and $X_{2}$ are the significant variables (temperature and packing density, respectively) and $\beta_{i}$ is the regression coefficient for each factor.

A design randomized complete block was also used in the experiments corresponding to application of FTase on aguamiel for the FOS synthesis. Here, SAS software version 9.0 was employed for such analysis.

\subsection{FOS synthesis using FTase enzyme}

\subsubsection{Fermentation study under the best process conditions}

In this section, a fermentation study under the best conditions of FTase production after optimization was performed. SSF assays were performed using aguamiel as culture medium (Initial $\mathrm{pH}$ 4.5 ) and polyurethane foam (PUF) as inert support (Mexican polyurethanes, Ramos Arizpe, Coahuila, Mexico). Column bioreactors were used and the following process conditions were applied: $70 \%$ moisture, inoculum of $2 \times 10^{7}$ spores/g of support, packing density $0.7 \mathrm{~g} / \mathrm{cm}^{3}, 32{ }^{\circ} \mathrm{C}$. Samples were withdrawn each $4 \mathrm{~h}$ for $32 \mathrm{~h}$. All experiments were done in triplicate.

For FTase activity assay, $100 \mu \mathrm{L}$ crude enzymatic extract were mixed with $900 \mu \mathrm{L}$ sucrose ( $4 \%$ in acetate buffer, pH 5.0, $50 \mathrm{mM}$ ) and incubated at $30^{\circ} \mathrm{C}$ for $20 \mathrm{~min}$ in a water bath. The reaction was stopped by boiling during $3 \mathrm{~min}$. As control was used a sucrose solution in buffer without source enzyme. Quantitative analysis of the product formed (kestose) was done by HPLC under the above described conditions. Calibration curve was established using commercial HPLC grade standard. Total FOS concentration was also determined.

Enzyme production was carried out under the best fermentation conditions (described above) during $28 \mathrm{~h}$. Aluminum trays were used for fermentation in order to obtain the greatest possible amount of crude extract for application on aguamiel for FOS synthesis enzymatic.

Table 1

Coded and real levels of factors evaluated in the Box-Hunter and Hunter design.

\begin{tabular}{llll}
\hline Factor & Lowest level $(-)$ & Highest level $(+)$ & Units \\
\hline Inoculum & $2 \times 10^{5}$ & $2 \times 10^{7}$ & spores/g support \\
Temperature & 25 & 30 & ${ }^{\circ} \mathrm{C}$ \\
Initial pH & 4.5 & 5.5 & $\mathrm{pH}$ units \\
Packing density & 0.2 & 0.5 & $\mathrm{~g} / \mathrm{cm}^{3}$ \\
\hline
\end{tabular}

Table 2

Experimental matrix obtained in Box-Behnken design.

\begin{tabular}{lllll}
\hline Trial & Inoculum & Temperature & Packing density & FTase activity $(\mathrm{U} / \mathrm{L})$ \\
\hline 1 & -1 & -1 & -1 & 0.00 \\
2 & -1 & 0 & 1 & 834.08 \\
3 & -1 & 1 & 0 & 1088.90 \\
4 & 0 & -1 & 1 & 359.00 \\
5 & 0 & 0 & 0 & 634.50 \\
6 & 0 & 1 & -1 & 646.44 \\
7 & 1 & -1 & 0 & 0.00 \\
8 & 1 & 0 & -1 & 157.58 \\
9 & 1 & 1 & 1 & 1347.58 \\
\hline
\end{tabular}

After obtained the extract was concentrated by lyophilization (batch $10 \mathrm{~mL}$ ), subsequently dissolved in $1.5 \mathrm{~mL}$ acetate buffer $\mathrm{pH}$ 5.0, $50 \mathrm{mM}$, filtered through Microcon Centrifugal filters $30 \mathrm{kDa}$ and centrifuged at $14,000 \mathrm{~g}$ for $12 \mathrm{~min}$ at $4{ }^{\circ} \mathrm{C}$. Three fractions were tested to determine FTase activity: (1) lyophilized extract; (2) upper extract, and (3) bottom extract.

2.9.2. Application of enzyme (FTase) on aguamiel for the synthesis FOS

FOS synthesis was carried out using aguamiel as substrate (sucrose content $37 \mathrm{~g} / \mathrm{L}$ ) and different conditions of incubation. Lyophilized extract resuspended in acetate buffer $\mathrm{pH}$ 5.0, $50 \mathrm{mM}$ was used in this stage.

The effect of incubation temperature on FOS synthesis by FTase was studied by adjusting the initial $\mathrm{pH}$ to 5.0. Three incubation temperatures were tested: 30,40 and $50^{\circ} \mathrm{C}$. First, $100 \mu \mathrm{L}$ of concentrated extract were mixed with $900 \mu \mathrm{L}$ aguamiel and incubated in a water bath for $1 \mathrm{~h}$. Finally, the reaction was stopped by heating in a water bath for $3 \mathrm{~min}$. As control it was used the enzyme in aguamiel at time 0 (reaction stopped immediately). The concentration of kestose formed was determined by HPLC as described above.

The major incubation temperature was selected to monitor the effect of initial pH. FOS production in aguamiel was studied using three different pHs: 5.0, 5.5 and 6.0. The reaction was done as described above. A temperature of $30^{\circ} \mathrm{C}$ was established in the first stage of application.

\subsubsection{Kinetic study of the FOS enzymatic synthesis}

Finally, a kinetic study was studied for the FOS enzymatic synthesis with the parameters of temperature and $\mathrm{pH}$ previously established $\left(30^{\circ} \mathrm{C}\right.$ with initial $\mathrm{pH}$ 5.0). The FOS synthesis was measured at a regular interval of 20 min up to $180 \mathrm{~min}$ of incubation. All experiments were made in triplicate.

\section{Results and discussion}

\subsection{First kinetic study}

Table 3 shows the enzymatic activities by A. oryzae DIA-MF in SSF. The maximum fructosyltransferase activity was at $42 \mathrm{~h}$; however, hydrolytic activity was also present during fermentation,

Table 3

Hydrolase and fructosyltransferase activities by Aspergillus oryzae DIA-MF.

\begin{tabular}{lll}
\hline \multicolumn{2}{l}{ Enzymatic activities (U/L) } & \\
\hline Fermentation time $(\mathrm{h})$ & Hydrolase $(\mathrm{Uh})$ & Fructosyltransferase $(\mathrm{Ut})$ \\
\hline 0 & 0 & 0 \\
18 & $3424 \pm 266$ & $2496 \pm 309$ \\
24 & $3049 \pm 134$ & $3085 \pm 1314$ \\
30 & $4914 \pm 602$ & $2402 \pm 267$ \\
42 & $5564 \pm 1524$ & $3625 \pm 777$ \\
48 & $6764 \pm 1830$ & $3585 \pm 173$ \\
\hline
\end{tabular}


increasing significantly between 24 and $48 \mathrm{~h}$. Transfructosylating activity at $24 \mathrm{~h}$ was $3085 \mathrm{U} / \mathrm{L}$, similar to the hydrolytic activity (3049 U/L). Therefore, $24 \mathrm{~h}$ of fermentation was selected because hydrolytic activity after this time was major than fructosyltransferase activity.

Table 4 shows the FOS production during fermentation. Maximum yield, $22.6 \mathrm{~g} / \mathrm{L}$, was obtained at $24 \mathrm{~h}$ of fermentation with a productivity of $0.94 \mathrm{~g} / \mathrm{L} \mathrm{h}$. FOS production using aguamiel of maguey as culture medium is a good alternative because aguamiel is a economic by-product, besides, Solid State Fermentation is a bioprocess inexpensive and easy to operate. Some works have been reported for the FOS production using sucrose as carbon source (Mussatto and Teixeira, 2010).

\subsection{Screening of significant variables by Box-Hunter and Hunter design}

The first kinetic study showed that $24 \mathrm{~h}$ of fermentation was the optimal time for the expression of fructosyltransferase and hydrolase enzymes. After, a Box-Hunter and Hunter design was applied to study factors that influence the response (FTase activity). Inoculum, packing density and temperature had a significant effect on the fructosyltransferase activity. On the other hand, initial $\mathrm{pH}$ had no effect on the enzymatic activity (FTase) indicating that $\mathrm{pH}$ of 4.5 is suitable for transfructosylation activity. Yun (1996) mentioned that values of $\mathrm{pH}$ between 4.5 and 5.5 are optimal for this enzyme. Since the three factors, named inoculum, packing density and temperature, were found to have a significant effect on the response, their optimal levels were established through a response surface methodology (RSM).

\subsection{Optimization studies of significant variables using a Box-Behnken design}

To evaluate the quadratic effects and interaction between the factors, a Box-Behnken design was used. An analysis of variance (ANOVA) (Table 5) revealed that incubation temperature $\left(X_{2}\right)$ and packing density $\left(X_{3}\right)$ had a linear effect statistically significant at a 95\% confidence level on the FTase production. A mathematical model was then obtained (Eq. (2)):

$Y=(634.504)+(453.986)\left(X_{2}\right)+(310.266)\left(X_{3}\right)$

The maximal theoretical value was reached with the highest temperature $\left(32^{\circ} \mathrm{C}\right)$ and the highest packing density $\left(0.7 \mathrm{~g} / \mathrm{cm}^{3}\right)$. Coefficient of determination $\left(R^{2}=0.91\right)$ was obtained. Lower values of these two factors significantly affected the response.

Fig. 1 shows the response surface plots obtained by the Statistical program. In Fig. $1 \mathrm{~A}$ is observed the effect of the temperature and packing density on the FTase production.

Enzymatic activity was not affected with inoculum rates used in this study. However, Fig. 1B and C, reveal that there is a trend of increased the enzymatic activity when increased packing density with inoculum rate (B) and incubation temperature with inoculum (C) but, in general, the interactions between factors tested did not show a significant effect in the response $(p<0.05)$. In a recent

Table 4

FOS production by Aspergillus oryzae DIA-MF by Solid-State Fermentation.

\begin{tabular}{lll}
\hline Fermentation time $(\mathrm{h})$ & Total FOS $(\mathrm{g} / \mathrm{L})$ & Productivity $(\mathrm{g} / \mathrm{L} \mathrm{h})$ \\
\hline 0 & $1.50 \pm 0.09$ & 0 \\
18 & $15.92 \pm 0.83$ & 0.88 \\
24 & $22.63 \pm 0.12$ & 0.94 \\
30 & $4.11 \pm 0.19$ & 0.13 \\
42 & $2.16 \pm 0.15$ & 0.05 \\
48 & 0 & 0 \\
\hline
\end{tabular}

work, Mussatto et al. (2012) studied the FTase and FOS production with the optimization of some factors, obtaining maximum values of FTase production at $30^{\circ} \mathrm{C}, 2 \times 10^{6}$ spores/g dry material and $70 \%$ moisture content. However, they used Aspergillus japonicus as producer fungus. Sangeetha et al. (2004) evaluated the FTase production in SSF by $A$. oryzae CFR 202 with various agro-industrial byproducts enriched with $60 \%$ of sucrose. Based on their results, the rice bran was major substrate for the FTase production reaching about $22 \mathrm{U} / \mathrm{mL}$. In the present study were obtained $1347 \mathrm{U} / \mathrm{L}$ at $24 \mathrm{~h}$ of fermentation with initial concentration of sucrose of $35 \mathrm{~g} / \mathrm{L}$ while Sangeetha et al. (2004) used $600 \mathrm{~g} / \mathrm{L}$ of sucrose as substrate. Finally, $32{ }^{\circ} \mathrm{C}$ incubation temperature, $0.7 \mathrm{~g} / \mathrm{cm}^{3}$ packing density and $2 \times 10^{7}$ spores/g of support were selected for futures studies.

\subsection{Enzymatic synthesis of FOS}

3.4.1. Kinetic study under the best conditions in optimization studies

After selected the best process conditions, other kinetic study was done but sampling each $4 \mathrm{~h}$ under same conditions of fermentation above mentioned. Fig. 2a, shows the production of FTase during $48 \mathrm{~h}$ of fermentation by A. oryzae DIA-MF. Here, maximum enzymatic activity was reached at $28 \mathrm{~h}$ with $1431 \mathrm{U} / \mathrm{L}$. Similar results were found in the optimization studies at $24 \mathrm{~h}$ of fermentation $(1347 \mathrm{U} / \mathrm{L})$. Therefore, the present study is reproducible under conditions tested. For obtaining enzymatic extract in tray, we selected $28 \mathrm{~h}$ of fermentation. In this section, also, protein in the extract was determined (Fig. 2b). Maximum protein content was also achieved at $28 \mathrm{~h}$ followed by an appreciable decrease at $32 \mathrm{~h}$. Probably exist a correlation between the two responses. However, more detailed experiments are needed to confirm these assumptions.

An analysis of FOS produced during the fermentation was also carried out. Fig. 2c shows measurement profiles of FOS. An increase of FOS was observed between 12 and $16 \mathrm{~h}$ of incubation $(15.5 \mathrm{~g} / \mathrm{L})$ with a productivity of $1.29 \mathrm{~g} / \mathrm{L} \mathrm{h}$. Several studies have focused in the FOS production obtaining yields of $50-60 \%$ from initial sucrose, but they particularly using high levels of sucrose between 15 and $60 \%$, while in this work only is used the sucrose present in the aguamiel $(35 \mathrm{~g} / \mathrm{L})$ that corresponds to 3.5\% (Sangeetha et al., 2004, 2005; Mussatto et al., 2009).

Crude extract in tray was obtained and was prosecuted in three steps. Results of the enzymatic activity (FTase) obtained at different steps, clearly were major activity in the lyophilized extract. Therefore, the lyophilized extracts were selected for the application of enzyme on aguamiel for the FOS production due to a major concentration of protein with FTase activity.

\subsubsection{Application of enzyme (FTase) on aguamiel for the synthesis of} FOS

In this part of the study, the FOS enzymatic synthesis was carried out for $1 \mathrm{~h}$ using aguamiel as substrate and lyophilized enzymatic extract. In Table 6 the effect of incubation temperature in the FOS synthesis is shown. As observed the FOS concentration was similar between temperatures tested with a FOS yield of $9 \mathrm{~g} / \mathrm{L}$ in $1 \mathrm{~h}$ of reaction. Then, $30^{\circ} \mathrm{C}$ was using for the following experiments because no significant difference between treatments. Yun (1996) mentioned that FTase activity is major when incubation temperatures between 50 and $60^{\circ} \mathrm{C}$ are used.

The effect of initial $\mathrm{pH}$ in the FOS enzymatic synthesis was monitored at 5.0, 5.5 and 6.0 (Table 6), the results showed no significant effect in the FOS synthesis under conditions tested. This agrees with the reported by Dhake and Patil (2007) who found an optimum activity fructosyltransferase of Penicillum purpurogenum at $\mathrm{pH}$ 5.5. However they mentioned that intracellular and extracellular FTase show stability in the $\mathrm{pH}$ range of 4.5-7.0. 
Table 5

Analysis of variance (ANOVA) for Box-Behnken design.

\begin{tabular}{|c|c|c|c|c|c|c|}
\hline & Sum of squares & Degrees of freedom & Mean squares & $F$-value & $p$-value & \\
\hline Inoculum (1L) & 58,190 & 1 & 58,190 & 1.56385 & 0.242636 & NS \\
\hline Inoculum (1Q) & 2442 & 1 & 2442 & 0.06563 & 0.803562 & NS \\
\hline Temperature (2L) & $2,473,243$ & 1 & $2,473,243$ & 66.46791 & 0.000019 & \\
\hline Temperature (2Q) & 3993 & 1 & 3993 & 0.10732 & 0.750708 & NS \\
\hline Packing density (3L) & 577,590 & 1 & 577,590 & 15.52262 & 0.003407 & \\
\hline Packing density (3Q) & 53,387 & 1 & 53,387 & 1.43476 & 0.261581 & NS \\
\hline $1 \mathrm{~L} \times 2 \mathrm{~L}$ & 85,687 & 1 & 85,687 & 2.30282 & 0.163451 & NS \\
\hline $1 \mathrm{~L} \times 2 \mathrm{Q}$ & 5205 & 1 & 5205 & 0.13987 & 0.717066 & NS \\
\hline Error & 334,886 & 9 & 37,210 & & & \\
\hline Total SS & $3,970,113$ & 17 & & & & \\
\hline
\end{tabular}

NS $=$ statistically not significant at $95 \%$ confidence interval.

Statistically significant at $95 \%$ confidence interval.
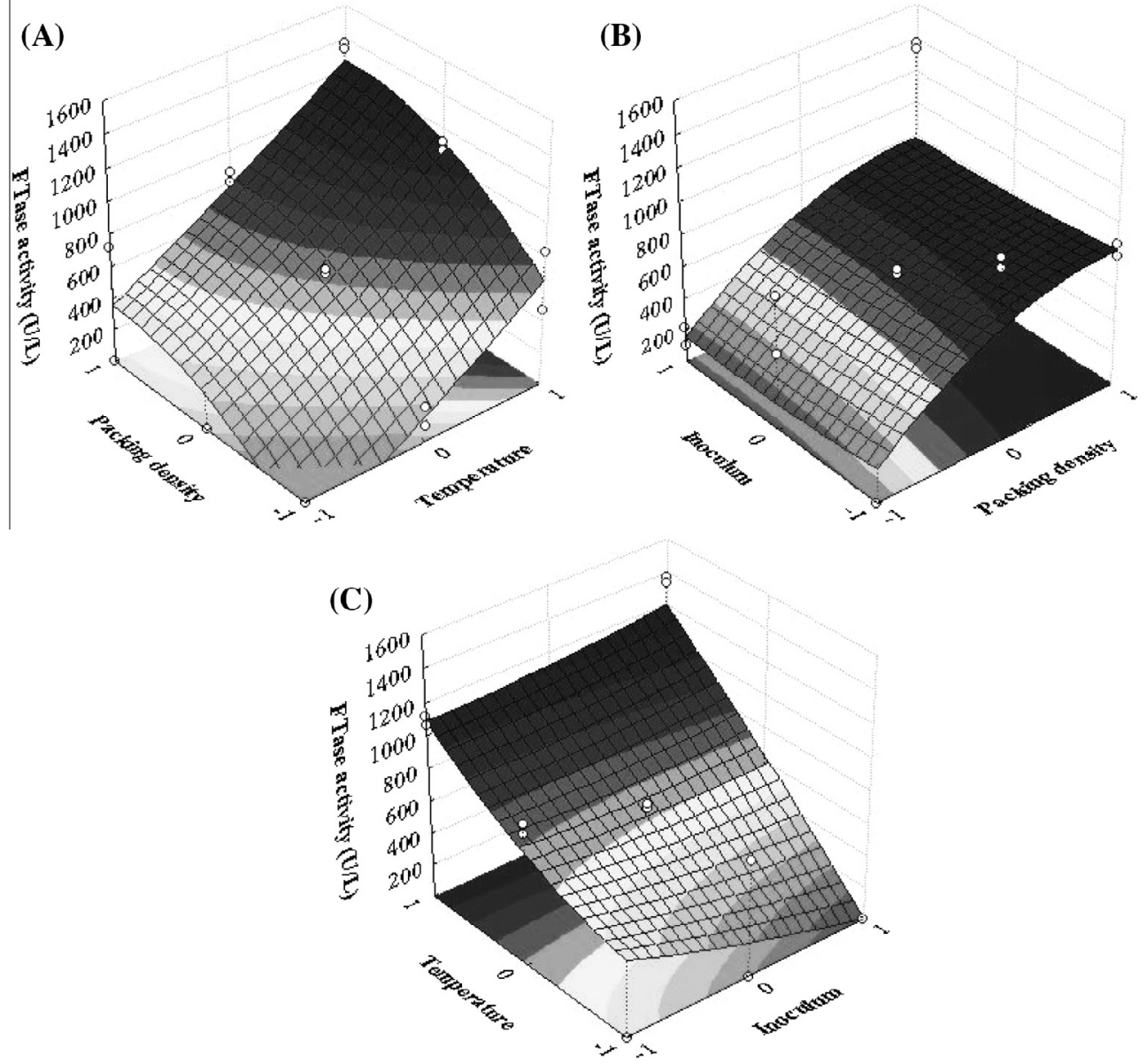

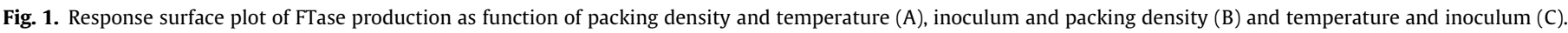

\subsubsection{Kinetic study of the FOS enzymatic synthesis}

A kinetic study was done with an incubation temperature of $30{ }^{\circ} \mathrm{C}$ to initial pH of 5.0. Fig. 3 shows that the maximum synthesis of FOS occurred in a period of $60-120$ min with yield between 8 and $11 \mathrm{~g} / \mathrm{L}$ of kestose. Sucrose is considered the best carbon source for FTase enzymes (Dhake and Patil, 2007). In this work, the sucrose present in aguamiel was used after a sterilization process (approximately 35-40 g/L). According to the Fig. 3 the biotransformation of sucrose and FOS synthesis were observed in $20 \mathrm{~min}$ of reaction.

On the other hand, the maximum FOS synthesis occurred during 80 at 120 min. Only $43.8 \%$ of the initial sucrose was transformed in FOS with yield of product/total substrate equal to
$0.30 \mathrm{~g} / \mathrm{g}$ and productivity of $0.097 \mathrm{~g} / \mathrm{L}$ min. Sangeetha et al. (2004) studied the FOS production by FTase from $A$. oryzae CFR 202 and obtained maximum FOS of $52 \%$ after $8 \mathrm{~h}$ of reaction, but high levels of sucrose were used as substrate (600 g/L).

\section{Conclusions}

The use of experimental designs allowed to identify the variables that significantly affected or favored the FTase production. The highest enzymatic activity (FTase) was obtained using an incubation temperature of $32{ }^{\circ} \mathrm{C}$ with a packing density of $0.7 \mathrm{~g} / \mathrm{cm}^{3}$. On the other hand, the inoculum rate and initial $\mathrm{pH}$ did not influence in this response. Also, the FOS production was possible using 


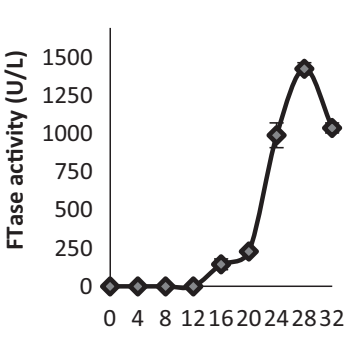

(a)
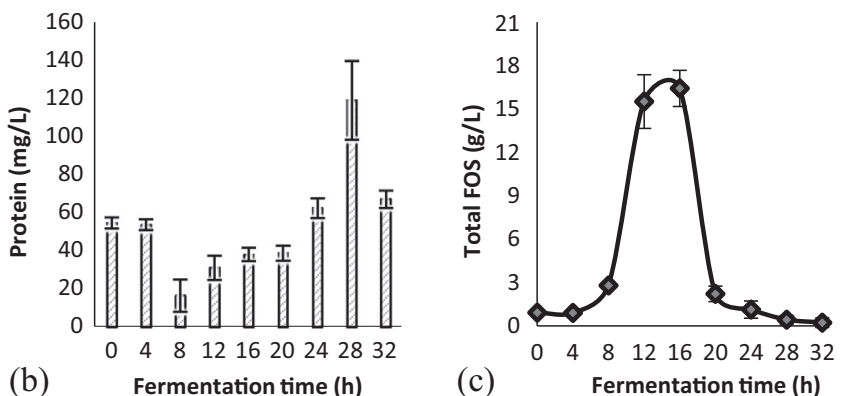

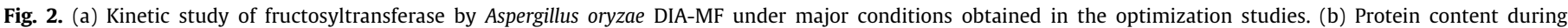
fermentation. (c) Kinetic study of FOS by Aspergillus oryzae DIA-MF under major conditions obtained in the optimization studies.

Table 6

Effect of incubation temperature and initial $\mathrm{pH}$ in the FOS production by FTase.

\begin{tabular}{|c|c|c|c|c|c|c|}
\hline \multirow[t]{2}{*}{ Factor } & \multicolumn{3}{|c|}{ Temperature effect $\left({ }^{\circ} \mathrm{C}\right)$} & \multicolumn{3}{|l|}{$\mathrm{pH}$ effect } \\
\hline & 30 & 40 & 50 & 5 & 5.5 & 6 \\
\hline Yield FOS (g/L) & $7.89 \pm 1.10^{\mathrm{a}}$ & $9.02 \pm 0.60^{\mathrm{a}}$ & $9.06 \pm 0.49^{\mathrm{a}}$ & $7.89 \pm 1.10^{\mathrm{a}}$ & $7.96 \pm 0.62^{\mathrm{a}}$ & $7.57 \pm 0.35^{\mathrm{a}}$ \\
\hline
\end{tabular}

Significance letter. Value statistically not significant at $95 \%$ confidence interval.

Note: tested temperatures at $\mathrm{pH} 5.5$. Setting the temperature $\left(30^{\circ} \mathrm{C}\right)$, initial $\mathrm{pH}$ was tested.

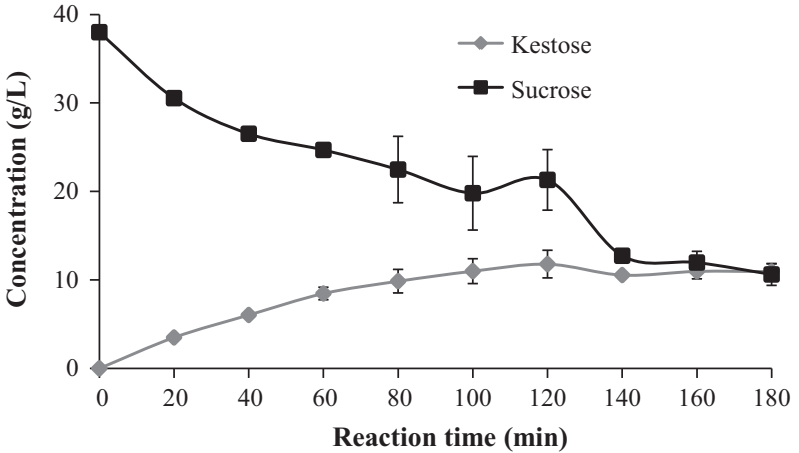

Fig. 3. FOS production during $180 \mathrm{~min}$ of reaction.

aguamiel as substrate and concentrated enzyme in the reaction. Here, incubation temperature and initial $\mathrm{pH}$ did not influence the enzymatic activity. This work, is a first study on FOS production from aguamiel as culture medium. The results obtained indicate that the aguamiel represents economical alternative for the FOS and enzyme FTase industrial production.

\section{Acknowledgements}

Authors thank National Council for Science and Technology (CONACYT) of Mexico by the financial support through the project No. CB-2011-C01-167764. Author D. B. Muñiz-Márquez also thank CONACYT for the financial support during her postgraduate program (Doctorate) in Food Science and Technology offered by the University Autonomous of Coahuila, Mexico.

\section{References}

Antošová, M., Polakovič, M., 2001. Fructosyltransferases: the enzymes catalyzing production of fructooligosaccharides. Chem. Pap. 55, 350-358.

AOAC, 1990. In: Helrich, K. (Ed.), Official Methods of Analysis of the Association of Official Analytical Chemists. Association of Official Analytical Chemists, Arlington, USA.

Barthi, S., Krishan, S., Kumar, A., Rajak, K., Murari, K., Barthi, B., Gupta, K., 2013. Antidiabetic activity and molecular docking of fructooligosaccharides produced by Aerobasidium pollullans in polaxamer-407-induced T2DM rats. Food Chem. $136,813-821$
Batista, M., Simões, K., Barros, C., Pessoni, R., Braga, M., Ribeiro, R., 2013. Production of 6 -kestose by the filamentous fungus Gliocladium virens as affected by sucrose concentration. Micoscience 54, 198-205.

Bradford, M.M., 1976. A rapid and sensitive method for the quantification of microgram quantities of protein using the principles of protein-dye binding. Anal. Biochem. 72, 248-255.

Campana, A., Martínez, L., Villarreal, H., Civera, R., 2006. Carbohydrate and lipid digestibility of animal and vegetal ingredients and diets for juvenile Australian redclaw crayfish, Cherax quadricarinatus. Aquacult. Nutr. 12, 103-109.

Chen, S.C., Sheu, D.C., Duan, K.J., 2014. Production of fructooligosaccharides using $\beta$ fructofuranosidase immobilized onto chitosan-coated magnetic nanoparticles. J. Taiwan Inst. Chem. Eng. 45, 1105-1110.

Dhake, A.B., Patil, M.B., 2007. Effect of substrate feeding on production of fructosyltrasnferase by Penicillum purpurogenum. Braz. J. Microbiol. 38, $194-$ 199.

Dominguez, A.L., Rodrigues, L.R., Lima, N.M., Teixeira, J.A., 2014. An overview of the recent developments on fructooligosaccharide production and applications. Food Bioprocess Technol. 7, 324-337.

Dreywood, R., 1946. Qualitative test for carbohydrate material. Ind. Eng. Chem. 18, 499-505.

Driouch, H., Roth, A., Dersch, P., Wittmaann, C., 2010. Optimized bioprocess for production of fructofuranosidase by recombinant Aspergillus niger. Appl. Microbiol. Biotechnol. 87, 2011-2024.

Ganaie, M.A., Gupta, U.S., Kango, N., 2013. Screening of biocatalysts for transformation of sucrose in fructooligosaccharides. J. Mol. Catal. B Enzym. $97,12-17$.

Ganaie, M.A., Lateef, A., Gupta, U.S., 2014. Enzymatic trends of fructooligosaccharides production by microorganims. Appl. Biochem. Biotechnol. 172, 2143-2159.

Gonçalves, C., Rodríguez, R.M., Gomes, N., Teixeira, J.Á., Belo, I., 2010. Adaptation of dinitrosalicylic acid method to microtiter plates. Anal. Methods 2, 2046-2048.

Hernalsteens, S., Maugeri, F., 2008. Properties of thermostable extracellular FOSproducing fructofuranosidase from Cryptococcus sp. Eur. Food Res. Technol. 228, $213-221$.

Hidaka, H., Hirayama, M., Sumi, N., 1988. A fructooligosaccharide-producing enzyme from Aspergillus niger ATCC 20611. Agric. Biol. Chem. 52, 1181-1187.

Lateef, A., Gueguimkana, E.B., 2012. Utilization of cassava wastes in the production of fructosyltransferase by Rhizopus stolonifer LAU 07. Romanian Biotechnol. Lett. 17. 7309-7316.

Lim, J.S., Park, M.C., Lee, J.H., Park, S.P., Kim, S.W., 2005. Optimization of culture medium and conditions for Neo-fructooligosaccharides production by Penicillium citrinum. Eur. Food Res. Technol. 221, 639-644.

Maiorano, A.E., Piccoli, R., Sabino da Silva, E., De Andrade, M.F., 2008. Microbial production of fructosyltransferases for the synthesis of pre-biotics. Biotechnol. Lett. 30, 1867-1877.

Miller, G.L., 1959. Use of dinitrosalicylic acid reagent for determination of reducing sugars. Anal. Chem. 31, 426-428.

Monsan, P.F., Ouarné, F., 2009. Oligosaccharides derived from sucrose. In: Charalampopoulos, D., Rastrall, R. (Eds.), In Prebiotics and Probiotics Science and Technology. Springer Science Business Media, pp. 293-336.

Muñiz, D.B., Contreras, J.C., Rodríguez, R., Mussatto, S.I., Wong-Paz, J.E., Teixeira, J.A., Aguilar, C.N., 2015. Influence of thermal effect on sugar composition of Mexican Agave syrup. CyTA J. Food. http://dx.doi.org/10.1080/19476337.2015.1028452. 
Mussatto, S.I., Aguilar, C.N., Rodrigues, L.R., Teixeira, J.A., 2009. Fructooligosaccharides and $\beta$-fructofuranosidase production by Aspergillus japonicus immobilized on lignocellulosic materials. J. Mol. Catal. B Enzym. 59, $76-81$.

Mussatto, S.I., Ballesteros, L., Martins, S., Maltos, D., Aguilar, C.N., Teixeira, J.A. 2013. Maximization of fructooligosaccharides and $\beta$-fructofuranosidase production by Aspergillus japonicus under solid-state fermentation conditions. Food Bioprocess Technol. 6, 2128-2134.

Mussatto, S.I., Prata, M.B., Rodrigues, L.R., Teixeira, J.A., 2012. Production of fructooligosaccharides and $\beta$-fructofuranosidase by batch and repeated batch fermentation with immobilized cells of Penicillum expansum. Eur. Food Res. Technol. 235, 13-22.

Mussatto, S.I., Teixeira, J.A., 2010. Increase in the fructooligosaccharides yield and productivity by solid-state fermentation with Aspergillus japonicus using agroindustrial residues as support and nutrient source. Biochem. Eng. J. 53, 154157.

Panesar, P.S., Bali, V., Kumari, S., Babbar, N., Oberoi, H.S., 2014 Prebiotics. In: Brar, S. K., Dhillon, G.S., Soccol, C.R (Eds.), Biotransformation of Waste Biomass into High Value Biochemicals. Springer Science Business Media, New York, pp. 237262

Pearson, T.R., Maita, Y., Lalli, C.M., 1984. A Manual of Chemical and Biological Methods for Seawaters Analysis, first ed. Pergamon Press, New York.
Pons, T., Hernández, L., Batista, F., Chinea, G., 2000. Prediction of a common $\beta$ propeller catalytic domain for fructosyltransferases of different origin and substrate specificity. Protein Sci. 9, 2285-2291.

Rodrigues, D., Rocha Santos, T.A.P., Pereira, C.I., Gomes, A.M., Malcata, F.X., Freitas, A C., 2011. The potential effect of FOS and inulin upon probiotic bacterium performance in curdled milk matrices. LWT Food Sci. Technol. 44, 100-108.

Sangeetha, P.T., Ramesh, M.N., Prapulla, S.G., 2004. Production of fructosyltransferase by Aspergillus oryzae CFR 202 in solid-state fermentation using agricultural by-products. Appl. Microbiol. Biotechnol. 65, 530-537.

Sangeetha, P.T., Ramesh, M.N., Prapulla, S.G., 2005. Fructooligosaccharide production using fructosyl transferase obtained from recycling culture of Aspergillus oryzae CFR 202. Process Biochem. 40, 1085-1088.

Šedová, M., Illeová, V., Antošová, M., Annus, J., Polakovič, M., 2014. Production of fructosyltransferase in mechanically stirred and air-lift bioreactors. Chem. Pap. $68,1639-1648$.

Yildiz, S. 2011. The metabolism of fructooligosaccharides and fructooligosaccharide-related compounds in plants. Food Rev. Int. 27, 16-50.

Yun, J.W., 1996. Fructooligosaccharides-occurrence, preparation and application. Enzyme Microb. Technol. 19, 107-117. 